\title{
VOJENSRRA SOCIOLOGE
}

Tento článek analyzuje nový prvek českého trestního práva, vojenské trestné činy s předsudečným motivem, které jsou obsaženy v trestním zákoníku č. 40/2009 Sb., jenž vstoupil v účinnost dne 1. 10. 2010, v hlavě XII s názvem „Trestné činy vojenské“. [1] Objevily se tam i kvalifikované skutkové podstaty několika trestných činů, které spadají do oblasti tzv. trestných činů s předsudečnou motivací, často též nazývanými zločiny z nenávisti. Cílem článku je objasnit podstatu těchto trestných činů a analyzovat možnosti jejich prípadné aplikace.

\section{Co jsou to trestné činy s předsudečným motivem?}

Jako odborný pojem se trestný čin s předsudečným motivem v nejobecnější míře se vztahuje ke zločinům, které jsou spáchány především proto, že obět' patří k určité skupině osob vymezené na základě široce pojatých znaků a pachatel má vůči této skupině osob předsudky. Anglický překlad tohoto pojmu zní „bias crime“. [2]

Je třeba zmínit skutečnost, že řada odborníků i oficiálních dokumentů (zvláště zahraničních) pracuje $\mathrm{v}$ obdobném významu s pojmem zločin z nenávisti (anglicky hate crime). [3] Nenávist však může být chápána jako př́liš expresivní či neurčitý pojem, a proto je $\mathrm{v}$ tomto článku preferován pojem trestný čin s predsudečným motivem, př́padně trestný čin s kolektivně předsudečným motivem (tento pojem byl doporučen i ve specializované expertize zpracované pro Ministerstvo vnitra ČR). [4]

At již bude používán ten či onen pojem, je důležité, že chráněnou charakteristikou je fundamentální nebo základní charakteristika, která je sdílena skupinou, jako je „rasa“, náboženství, národnost, jazyk nebo sexuální orientace. Cílem nenávisti může být osoba, skupina osob nebo majetek spojený se skupinou, která sdílí chráněnou charakteristiku“. [5] Ne všechny země využívající tohoto konceptu však chrání všechny uvedené charakteristiky (např. sexuální orientace není v ČR chráněna, jiné země si další charakteristiky přidávají (např. ČR ochranu třídy).

Je třeba rovněž zdůraznit, že koncepty předsudečných či nenávistných trestných činů nejsou totožné s konceptem extremisticky motivovaných trestných činů. Mohou se s nimi však překrývat. [6] Extremistický trestný čin vyžaduje to, aby jeho pachatel byl zaměřen a motivován odporem $\mathrm{k}$ demokratickému ústavnímu státu, a proto útočil na jeho hodnoty. Zpravidla tedy přináleží či se volně hlásí i k určitému ideologickému či náboženskému hnutí anebo čin alespoň páchá ve jménu jasného světonázoru. Proti tomu předsudečný či nenávistný trestný čin může být spáchán i osobou nepatř̌́cí mezi ideologicky vyprofilované extremisty. Na druhou stranu extremista může spáchat předsudečný trestný čin či trestný čin z nenávisti, může však spáchat i extremisticky motivovaný čin nepatřící do této kategorie (např. výtržnictví).

Koncept předsudečných trestných činů či trestných činů z nenávisti byl vytvořen ve Spojených státech amerických na přelomu sedmdesátých a osmdesátých let dvacátého 
století a v následujících desetiletích se silně projevil v tamním právním prostředí. Expandoval i do dalších geopolitických oblastí, včetně Evropy. Zde je podporován i na mezinárodní úrovni, zvláště pak Organizací pro bezpečnost a spolupráci v Evropě (OBSE). Podle ní je typologie trestně-právní legislativy proti zločinům z nenávisti následující.

Tab. 1: Typologie právní úpravy zločinů z nenávisti

\begin{tabular}{|l|l|}
\hline $\begin{array}{l}\text { Samostatné skutkové } \\
\text { podstaty }\end{array}$ & Předsudečný (“bias“) motiv je integrálním prvkem definice skutkové podstaty. \\
\hline \multirow{2}{*}{ Zpřísnění trestů } & Obecné zpřísnění trestů za předsudečný motiv. \\
\cline { 2 - 2 } & $\begin{array}{l}\text { Specifické zpřísnění trestů (zpřísnění trestů za předsudečný motiv pouze } \\
\text { u určitých skutkových podstat). }\end{array}$ \\
\hline
\end{tabular}

Zdroj: [7]

To, co je nazýváno „,bias crime“ či „,hate crime“, se v právních řádech mnoha evropských zemí objevilo již dávno před příchodem ,,amerického konceptu“, jen to tak nebylo nazýváno (normy proti šíření rasové či náboženské nenávisti měly ostatně i komunistické státy). Nicméně pod vlivem internacionalizace a evropeizace právního diskurzu byly i tyto „staré" trestné činy v odborné literatuře i vládních dokumentech do uvedených konceptů přirazeny. Koncept „,předsudečných zločinů“ či „,zločinů z nenávisti“ však doposud není na evropské ani mezinárodní úrovni zcela ujednocen. [8]

\section{Předsudečné trestné činy v českém právu}

V českém trestním právu není přímo používán pojem předsudečné trestné činy či trestné činy z nenávisti. Nicméně ustanovení práva v ČR v zásadě odpovídají uvedeným kategoriím vymezených Organizací pro bezpečnost a spolupráci v Evropě. To, co je nazýváno obecným zpřísněním trestů, je dle české právní terminologie přitěžující okolností, specifickým zpřísněním trestů je pak dle české právní terminologie kvalifikovaná skutková podstata. [4] Kvalifikovaná skutková podstata popisuje podle Encyklopedie o právu Iuridictum okolnosti spáchání trestního činu. Kvalifikované skutkové podstaty jsou pak stanoveny pro většinu trestných činů, v některých případech i ve více stupních, podle závažnosti. [9] Využití předsudečného motivu v českém trestním zákoníku je zachyceno v tab. 2.

Tab. 2: Předsudečné trestné činy v trestním zákoníku

\begin{tabular}{|c|c|}
\hline 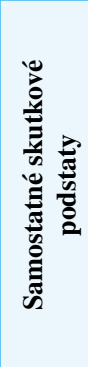 & $\begin{array}{l}\text { Předsudečný ("bias“) motiv je integrálním prvkem definice skutkové podstaty: } \\
\text { § } 352 \text { Násilí proti skupině obyvatelů a proti jednotlivci (pouze odst. 2) } \\
\text { § } 355 \text { Hanobení národa, rasy, etnické nebo jiné skupiny osob } \\
\text { § } 356 \text { Podněcování k nenávisti vůči skupině osob nebo k omezování jejich práv a svobod } \\
\text { § } 400 \text { Genocidium } \\
\text { § } 401 \text { Útok proti lidskosti (odst. 1, písm. e) } \\
\text { § } 402 \text { Apartheid a diskriminace skupiny lidí } \\
\text { § } 403 \text { Založení, podpora a propagace hnutí směřujícího k potlačení práv a svobod člověka } \\
\text { § } 404 \text { Projev sympatií k hnutí směřujícímu k potlačení práv a svobod člověka } \\
\text { § } 405 \text { Popírání, zpochybňování, schvalování a ospravedlňování genocidia } \\
\text { § } 413 \text { Perzekuce obyvatelstva }\end{array}$ \\
\hline
\end{tabular}




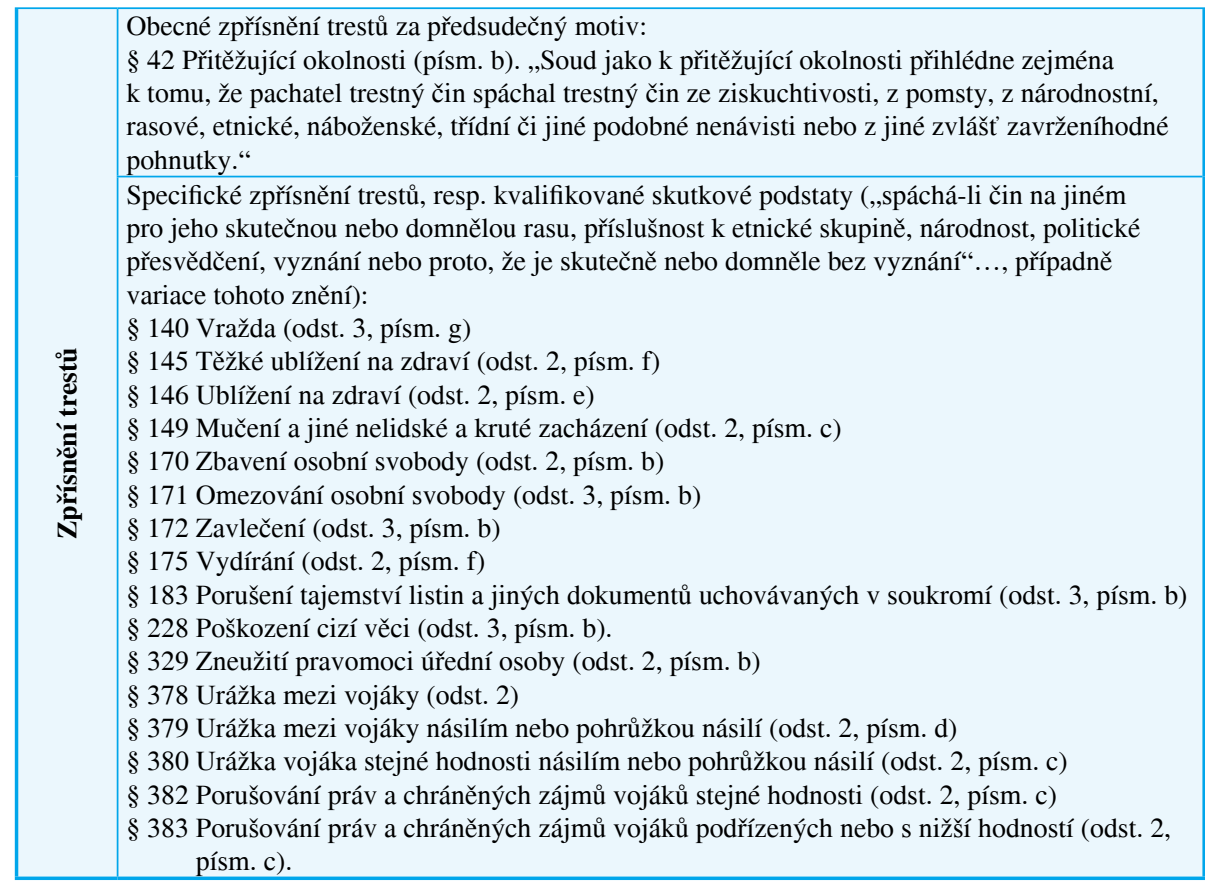

Zdroj: [4]

\section{Předsudečný motiv v hlavě XII trestního zákoníku}

Zatímco řada výše zmíněných předchozích předsudečných trestných činů v současném trestním zákoníku již v různé formě existovala i v dřívějších československých a českých právních normách, u trestných činů vojenských (které obecně mají na území českých zemí velmi dlouhou tradici) je předsudečná motivace novým prvkem. [10]

Je přitom možné zmínit skutečnost, že již v roce 1999 byly tyto trestní činy zavedeny tehdejším prezidentem Billem Clintonem do Vojenského trestního zákoníku v USA. [11] Důvodem je specifický zájem na klidném soužití osob ve vojenském prostředí, kde vzájemné urážky (zvláště z předsudečných motivů) mohou narušit vzájemnost a akceschopnost ozbrojených sil.

Z hlediska vojenských trestných činů v hlavě dvanácté (trestné činy vojenské) jsou ve vztahu k tématu článku podstatné vybrané trestné činy z dílu 1 (Trestné činy proti vojenské podřízenosti a vojenské cti), u nichž je zavedena zvláštní skutková podstata (a tedy tvrdší trest). Znění základní skutkové podstaty, výše trestu u ní a srovnání výše trestu u kvalifikované skutkové podstaty, jsou zachyceny v tabulce 3 (str. 143).

U trestných činů podle $§ 382$ a $§ 383$ TrZ je trestná i příprava takového jednání. [1]

\section{Důležité pojmy při vymezení vojenských předsudečných trestných činů}

Při aplikaci vojenských předsudečných trestných činů je třeba upřesnit i obsah důležitých pojmů, které se v uvedených skutkových podstatách objevují. Nejprve budou 


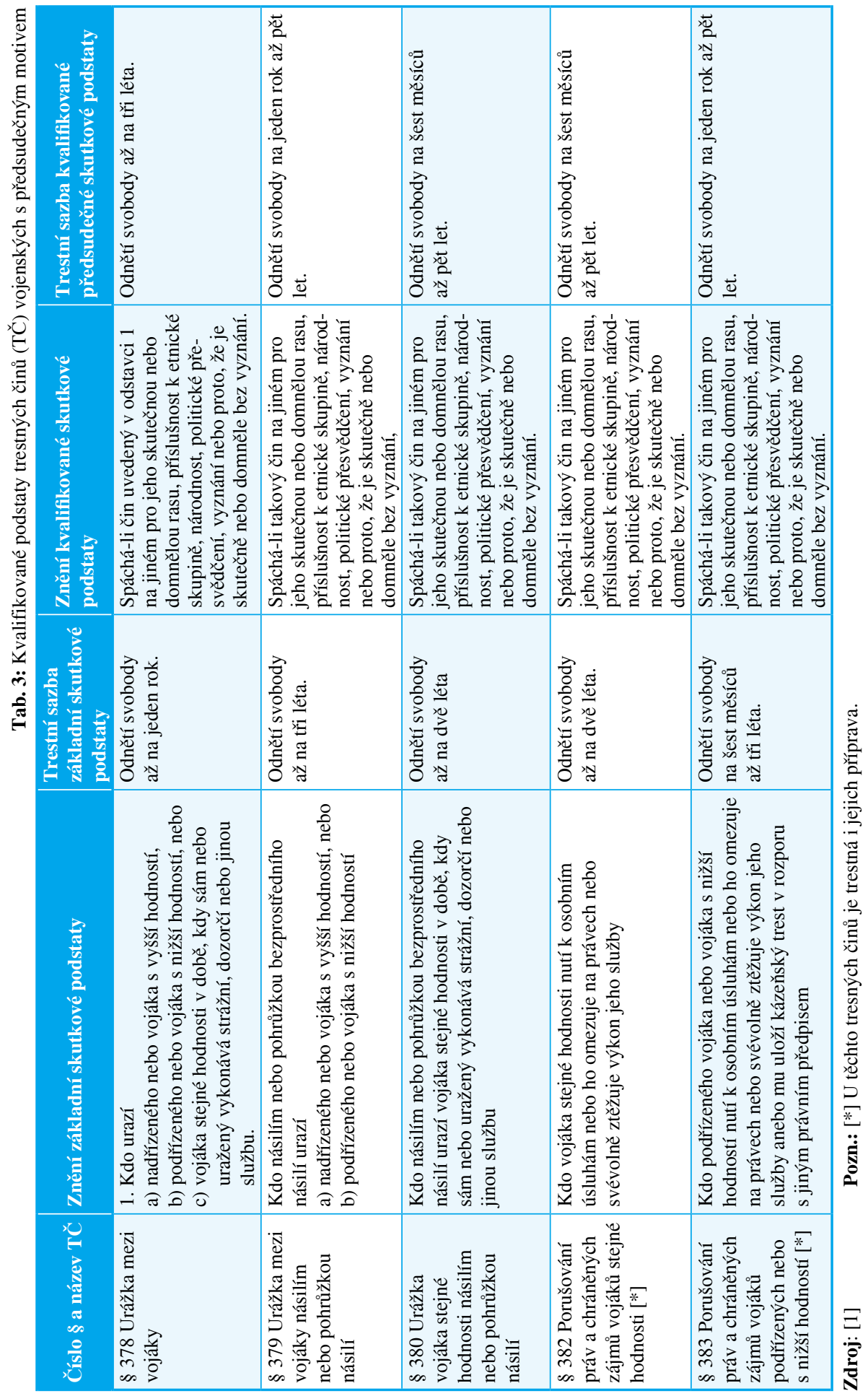


vymezeny chráněné charakteristiky z kvalifikovaných skutkových podstat a poté vybrané pojmy ze základních skutkových podstat.

Rasa je podle dosavadní judikatury a na ni vázané jurisprudence chápána v ČR jako biologický fakt, nikoliv tedy jako sociální konstrukt (což preferují některá díla z oblasti sociálních věd). [12] Za rasu se ve smyslu trestního práva považuje „skupina lidí, která se od jiných liší somatickými a dalšími společnými biologickými rysy (barva kủže, tvar lebky, nosu, barva očí, barva a tvar vlasů, výška, proporce a členění těla)“. [3]

Etnickou skupinou ,je historicky vzniklá skupina lidí, kterou spojuje společný původ, zvláštní kulturní znaky (jazyk), mentalita a tradice. Př́́slušníci určité etnické skupiny mají povědomí vzájemné sounáležitosti, a zároveň odlišnosti od jiných společenství lidí a jsou spojováni názvem etnika nebo jménem, kterým je etnikum označováno. Etnická skupina žije zpravidla v početní menšině v rámci jiného společenství (např. v České republice romské etnikum)“. [13]

Národností se podle Jiř́ho Herczega rozumí ,př̌́slušnosti jedince i skupiny k určitému národu nebo národnostní menšině projevující se zejména vlastní kulturou, tradicemi či jazykem“. [3]

Politické přesvědčení je vztah k určitým konsistentním politickým ideám či k ideologiím a politickým proudům. Chráněna jsou však pouze taková politická přesvědčení, která nejsou v rozporu s platnými právními předpisy [3] (právní ochrany se tedy nemůže domáhat napřs. fašista, který by byl urážen).

Ohledně citlivé otázky komunismu v ČR je třeba zkoumat, zda jsou dotčeny takové směry komunismu, které jsou v ČR chápány jako protiprávní (tj. takové, jejichž program či doktrína obsahují anebo usilují uchopit moc násilím, po jakémkoliv získání moci vyloučit svobodné volby, uznávají učení o diktatuře proletariátu, hlásají teorii nebo praxi vedoucí úlohy jedné politické strany apod.). [14] Jinak by měla být poskytována ochrana i komunistickému politickému přesvědčení.

Náboženským vyznáním je vyznávání víry v určitém náboženství a osobou bez vyznání je dle Herczega ten, kdo vědomě odmítá jakékoliv náboženství či víru. [3] I v oblasti náboženského vyznání lze dovodit, že chráněna budou pouze tolerantní a zákonem akceptovaná náboženská vyznání, [15] nikoliv různé nenávistné náboženské směry (např. džihádismus).

Pokud se týká pojmu urážka (v § 378, § 379 a $§ 380$ TrZ), rozumí se jí podle Jiř́ho Jelínka a kol.: „Útok na lidskou či vojenskou důstojnost jiného vojáka, jímž je snižována čest a vážnost jeho funkce nebo hodnosti. Urážlivý projev nemusí být spáchán veřejně ani před další osobou, dokonce ani v př́tomnosti uraženého. Urážka může být spáchána nejen verbálně, ale i písemně, hrozbou nebo gestem.“ [16] Stejní autoři pak vymezují použití násilí jako „použití fyzické síly k překonání nebo zamezení kladeného či očekávaného odporu“ [16] a pohrůžkou bezprostředního násilí „,pohrůžka násilím, která má být ihned vykonána, např. násilím proti životu, zdraví nebo majetku napadeného, ten pak nemá volnost rozhodování a nezbývá mu, než se podrobit. Hrozba může směřovat též $\mathrm{k}$ tomu, že tohoto násilí bude použito proti jiné osobě, než je ten, na jehož vůli chce pachatel působit“. [16] Jak vyplývá z § 119 trestního zákoníku, trestný čin je spáchán násilím i tehdy, je-li spáchán na osobě, kterou pachatel uvedl do stavu bezbrannosti lstí nebo jiným podobným způsobem. [1]

Vymezení pojmů a skutků v $\S 382$ a $§ 383$ TrZ je podle Jiř́iho Jelínka a kolektivu následující: „Nutit jiného znamená vnucovat mu vůli pachatele, aby obět něco konala, trpěla nebo opomenula. Nutit je možné násilím, výhružkami, využitím tísně ... 
Neoprávněnými osobními úsluhami jsou úkony vykonávané ve prospěch jiné osoby, na které tato osoba nemá právo, a nejsou vykonávané v zájmu ozbrojených sil nebo v jejich prospěch, ale jsou vykonávané za jinou osobu, která byla povinna je vykonat (např. nucení vojáků čistit za jiného zbraň, uklízet za jiného, nosit jídlo, dělat osobního sluhu apod.).

Omezovat vojáka na právech znamená neoprávněně rozšiřovat rozsah zákonného omezení práv, svobod a chráněných zájmů. Může se jednat o omezování účasti na kulturních či sportovních aktivitách, vycházkách, odpočinku etc.

Svévolné ztěžování výkonu služby znamená ztížení výkonu konkrétního služebního úkonu nebo ztěžování výkonu služby všeobecně.“ [16] Představit si tedy lze napřr. úmyslné výrazné znečištění prostor, které byly přiděleny určitému vojáku k úklidu nebo systematické kladení překážek při plnění svěřených úkolů.

\section{Kdo může spáchat vojenské předsudečné trestné činy}

Uvedené trestné činy podle $\S 378, \S 379, \S 380, \S 382$ a $§ 384$ TrZ mohou být spáchány vojáky a - jak vyplývá ze znění $\$ 399$ TrZ - první tři z uvedených trestných činů $(\S 378, \S 379, \S 380)$ i příslušníky bezpečnostních sborů. Vojákem se podle $\S 114$ odst. 4 TrZ rozumí

a) voják v činné službě,

b) voják mimo činnou službu,

c) prŕíslušník bezpečnostního sboru (u již zmíněných $§ 378, \S 379, \S 380$ ),

d) válečný zajatec. [1]

Vymezení vojáka v činné službě vyplývá z § 1 zákona č. 585/2004 Sb., o branné povinnosti a jejím zajištování (branný zákon). Uvádí se v něm:

(1) Branná povinnost je povinnost státního občana České republiky plnit úkoly ozbrojených sil České republiky; zahrnuje povinnost občana podrobit se odvodnímu řízení, vykonávat vojenskou činnou službu a plnit další povinnosti stanovené tímto zákonem.

(2) Vojenskou činnou službou mimo stav ohrožení státu nebo mimo válečný stav je služba vojáka z povolání ve služebním poměru podle zvláštního právního předpisu) a vojenské cvičení nebo výjimečné vojenské cvičení.

(3) Vojenskou činnou službou za stavu ohrožení státu nebo válečného stavu je mimořádná služba.

(4) Dnem právní moci rozhodnutí o schopnosti občana vykonávat vojenskou činnou službu vydaným při odvodním řízení se občan stává vojákem. Voják je povinen vojenskou činnou službu včas nastoupit a osobně vykonávat. Voják, který plní některou z povinností podle odstavce 2 nebo 3, je vojákem v činné službě. [16]

Bezpečnostním sborem se podle $§ 1$ zákona č. 361/2003 Sb., v platném znění, rozumí Policie České republiky, Hasičský záchranný sbor České republiky, Celní správa České republiky, Vězeňská služba České republiky, Generální inspekce bezpečnostních sborů, Bezpečnostní informační služba a Úřad pro zahraniční styky a informace. [17]

Vymezení válečných zajatců vyplývá z ženevských úmluv, zvláště pak z článku 4 Ženevské úmluvy o zacházení s válečnými zajatci ze dne 12. srpna 1949 [18] a z článku 44 Dodatkového protokolu k Ženevským úmluvám z 12. srpna 1949 o ochraně obětí mezinárodních ozbrojených konfliktů (Protokol I) a článek 4 Dodatkového protokolu 
k Ženevským úmluvám z 12. srpna 1949 o ochraně obětí ozbrojených konfliktů nemajících mezinárodní charakter (Protokol II). [19] Podrobný rozbor právního pojmu válečný zajatec je nad rámec tohoto článku, přičemž však lze odkázat na jeho precizní vymezení v odborné literatuře i přehledových manuálech. [20]

\section{Exkurz: Další předsudečné trestné činy a přestupky z hlediska vojáků}

Jak již bylo uvedeno, vojenských trestných činů se mohou dopustit pouze vojáci. Vojáci však samozřejmě mohou spáchat i jiné než vojenské předsudečné trestné činy, např. pokud by voják hanobil nevojáka pro jeho pro jeho rasu či etnickou př́slušnost apod. Na vojáky se tedy vztahují i další ustanovení trestního zákoníku z hlediska působnosti vymezené $\mathrm{v}$ jeho hlavě první. [1]

Pro vojáky jsou prítom relevantní i ustanovení přestupkového práva v oblasti předsudečných deliktů. Jak vyplývá z ustanovení o kázeňských přestupcích v $\$ 28$ ods. 2) zákona č. 220/1999 Sb., o průběhu základní nebo náhradní vojenské služby a vojenských cvičení a o některých právních poměrech vojáků v záloze [21] a § 51 odst. 2 zákona č. 221/1999 Sb. o vojácích z povolání, je kázeňským přestupkem též jednání vojáka označené za přestupek ve zvláštním právním předpise, [22] kterým je např. zákon č. 200/1990 Sb., o přestupcích.

$\mathrm{V}$ přestupkovém zákoně je přitom v rámci $\S 49$ přestupky proti občanskému soužití v písm. e) uvedeno, že přestupku se dopustí ten, kdo působí jinému újmu pro jeho př́íslušnost k národnostní menšině nebo pro jeho etnický původ, pro jeho rasu, barvu pleti, pohlaví, sexuální orientaci, jazyk, víru nebo náboženství, pro jeho politické nebo jiné smýšlení, členství nebo činnost v politických stranách nebo politických hnutích, odborových organizacích nebo jiných sdruženích, pro jeho sociální původ, majetek, rod, zdravotní stav anebo pro jeho stav manželský nebo rodinný. Za to lze uložit pokutu až do výše 20 000,- Kč. [23]

Orgány s kázeňskou pravomocí vůči vojákům pak takový přestupek projednávají a ukládají za něj sankce. [22] Obsah chráněných charakteristik je v přestupkovém zákoně širší než v trestním zákoníku, je tedy podle něj možné trestat např. i to, pokud by voják jinému vojáku působil z předsudečné motivace újmu pro jeho sexuální orientaci, pro jeho zdravotní stav či majetkové poměry.

\section{Závĕr}

Trestní zákoník (TrZ) vstoupil v účinnost dne 1. 1. 2010. Z dosavadních úředních dokumentů nevyplývá, že by vojenské trestné činy s předsudečnou motivací již byly v praxi orgánů činných $\mathrm{v}$ trestním rrízení aplikovány. [24, 25] Jak je patrné z předchozího přehledu, předsudečná motivace zvyšuje trestní sazby jak u urážek a násilí mezi vojáky, tak i u činů souvisejících s tzv. šikanou. Po zrušení povinné základní vojenské služby je dopad ustanovení o předsudečných trestných činech menší, než mohl být při dřívějším zavedení, mj. i s ohledem na relativně malý počet profesionálních vojáků z etnických menšin na rozdíl od „multietnické“ branecké armády (zvláště ve federálním období). $\mathrm{V}$ př́padě znovuzavedení povinných odvodů či po mobilizaci by počet uvedených trestných činů mohl narůstat. Pokud budou př́slušníci AČR při některých operacích 
zajímat válečné zajatce, vztahují se uvedené předsudečné trestné činy i na ně. Případnou aplikaci zkoumaných trestných činů je třeba pozorně sledovat, protože judikatura bude upřesňovat celkové možnosti jejich využívání pro potlačování negativních jevů v ozbrojených silách, které souvisí s kolektivními předsudky.

\section{Použitá literatura:}

[1] Zákon č. 40/2009 Sb., trestní zákoník.

[2] MOULISOVÁ, Marcela. Rasově motivovaná trestná činnost. In Zapletal, Josef a kol. (eds.). Aktuální problémy kriminologie. Praha: Policejní akademie ČR, 2008, 199-225.

[3] HERCZEG, Jiří. Trestné činy z nenávisti. Praha: ASPI, Wolters Kluwer, 2008.

[4] MAREŠ, Miroslav. Problematika hate crime: Zahraniční zkušenosti a možnost aplikace tohoto př́stupu v $\check{C} R$ s důrazem na trestné činy z nenávisti proti cizincům. Praha: Ministerstvo vnitra ČR, 2011.

[5] ORGANISATION FOR SECURITY AND COOPERATION IN EUROPE. ODIHR and the Battle against Hate Crime. Factsheet. Warsaw. OSCE ODIHR, 2011, http.//www.osce.org/odihr/68668? download=true [ověřeno $\mathrm{k} 5$. květnu 2012]

[6] KALIBOVÁ, Klára. Násilí z nenávisti a média. In Kalibová Klára (eds.). Násilí z nenávisti, rasismus a média: Jak nepsat černobíle o barevném světě. Praha: In Iustitita 2011, str. 10-25, ISBN 978-80-2600097-6, dostupné na http://www.in-ius.cz/dwn/nzn-rasis-media/in-iustitia-publikace-media.pdf.

[7] ORGANISATION FOR SECURITY AND COOPERATION IN EUROPE. Hate Crime Laws: A Practical Guide. Warsaw: OSCE ODIHR, 2009.

[8] GARLAND, Jon - CHAKRABORTI, Neil. Divided by a common concept? Assessing the implications of different conceptualizations of hate crime in the European Union. European Journal of Criminology, Vol. 9, No. 1, 2012, 38-51.

[9] Kvalifikovaná skutková podstata. In Encyklopedie o právu Iuridictum. Dostupné na http//iuridictum. pecina.cz/w/Kvalifikovan\%C3\%A1_skutkov\%C3\%A1_podstata [ověřeno k 5. květnu 2012].

[10] Důvodová zpráva k návrhu trestního zákoníku, 2009, dostupné na http//trestnizakonik.cz/navrh/duvodova-zprava.html [ověřeno $\mathrm{k} 5$. květnu 2012].

[11] BRODER, John M. Clinton Adds Stiffer Penalities to Military Code for Bias Crimes. The New York Times, October 07, 1999, http.//www.nytimes.com/1999/10/07/us/clinton-adds-stiffer-penalities-tomilitary-code-for-bias-crimes.html [ověřeno k 5. květnu 2012].

[12] ŠMAUSOVÁ, Gerlinda. „Rasa“ jako rasistická konstrukce. Sociologický časopis, roč. 3, č. 4, 1999, 433-446.

[13] ŠAMAL, Pavel - PÚRY, František - RIZMAN, Stanislav. Trestní zákon. Komentár. II. díl. 6., doplněné a přepracované vydání. Praha: C. H. Beck 2004.

[14] Nález Ústavního soudu České a Slovenské Federativní Republiky, 5/1992.

[15] KŘ́YŽ̌, Jakub. Zákon o církvích a náboženských společnostech: Komentár. Praha: C. H. Beck, 2010, 384 str. ISBN 978-80-7400-362-2.

[16] JELÍNEK, Jiří a kol. Trestní zákoník a trestní rád s poznámkami a judikaturou. Praha: Leges, 2009; Zákon č. 585/2004 Sb., o branné povinnosti a jejím zajištování (branný zákon), v platném znění.

[17] Zákon č. 361/2003 Sb., o služebním poměru př́islušníků bezpečnostních sborů, v platném znění.

[18] Vyhláška Ministra zahraničních věcí č. 65/1954 Sb., o Ženevských úmluvách ze dne 12. srpna 1949. na ochranu obětí války.

[19] Sdělení federálního ministerstva zahraničních věcí č. 168/1991 Sb.

[20] JUKL, Marek. Ženevské úmluvy a dodatkové protokoly: Stručný prehled. 2. vydání. Praha: Český červený kř̌ž, 2009, http.//www.cck-cr.cz/docs/mhp/konvence.htm [ověřeno k 6. květnu 2012].

[21] Zákon č. 220/1999 Sb., o průběhu základní nebo náhradní vojenské služby a vojenských cvičení a o některých právních poměrech vojáků v záloze.

[22] Zákon č. 221/1999 Sb., o vojácích z povolání, ve znění zákona č. 254/2002 Sb.

[23] Zákon č. 200/1990 Sb., o přestupcích, ve znění zákona č. 273/2001 Sb.

[24] MINISTERSTVO VNITRA. Zpráva o problematice extremismu na území České republiky v roce 2010 a Vyhodnocení koncepce boje proti extremismu pro rok 2010 a ke koncepci boje proti extremismu pro rok 2011. Praha: Ministerstvo vnitra ČR, 2011.

[25] MINISTERSTVO VNITRA. Zpráva o situaci v oblasti vnitřní bezpečnosti a veřejného pořádku na území $\check{C} R$ v roce 2011. Praha: Ministerstvo vnitra ČR, 2012, http.//www.mvcr.cz/clanek/zprava-o-situaci-v-oblasti-vnitrni-bezpecnosti-a-verejneho-poradku-na-uzemi-cr-v-roce-2011.aspx [ověřeno k 6. květnu 2012]. 